growth of knowledgre makes it necessary for the teacher of any branch of applied science to be a specialist of a high order, and the most accomplished specialist cannot impart the full advantage of his knowledge without that complete provision of apparatus for rescarch and instruction which this college will supply.

"The college has already given admirable results, and we may well look for a steady increase in the number of students and in the efficiency of the instruction provided.

"The thanks of the country are due to those publicspirited donors through whose gencrosity a large portion of the funds have been provided for this great work, and I join in your appreciation of their munificence. I think it is especially fitting that the great discoveries of the late Sir Henry Bessemer, to which the remarkable development of the engineering industries in the last half-century is largely due, should be commemorated by the equipment of the new laboratories of this institution."

\section{University of BirmisgihM.}

On July $;$ the King and Queen, accompanied by the Princess Victoria, performed the opening ceremony of the new buildings of the Birmingham University. Inasmuch as the founding of the Lniversity on the initiative of Mr. Chamberlain has been effected almost entirely by means of money subscribed by the inhabitants of the Birmingham district, the occasion was appropriately made to partake largely of the nature of a civic function.

The characteristic note of the proceedings may perhaps best be given by some quotations from the King's speeches. In replying to the address from the Corporation, after warmly commending the public spirit of the citizens, His Majesty said :- (ireat schenes such as that for providing your city with pure nater have been undertaken in the past, and have been brought to a successful issue; but none is worthier of support or more far-reaching in its scope than the establishment and extension of the great University in which you have taken so important a part." Later, in reply to an address from the Chamber of Commerce expressing the recognition by the commercial and mercantile classes of the value of the advancement of higher education, his Majesty said :- "I am glad to !earn that the commercial community have been faithful and generous supporters of the Lniversity. I feel assured that your expectations of advantage's to be derived from the Faculty of Commerce in training the future captains of industry will be realised."

After a luncheon at the Council House, their Majesties drove, through roads lined with enthusiastic spectators, to the new buildings at Bournbrook, a distance of about three miles. The opening ceremony took place in the great hall of the University, which was occupied largely by members of the Lniversity and representatives of other educational bodies.

The University address was read by Sir Oliver Iodge, and the following characteristic passage may be quoted :"Guided by our Chancellor, whose inability to be present on this memorable occasion we deeply regret, we have made no attempt to give an appearance of finality to our present undertaking: Rather do we regard it as capable of indefinite expansion. Whilst the field of scientific research is ever widening, and its discoveries demand yearlv a fresh application to the facts of life, the claims of the humaner studies become none the less imperative; and in both these branches of human activity, which can only flourish side by side, we realise the need of continual development. But we believe that the work which we have begun, upon which this day your Majesties set the seal of your Royal approbation, can confidently be entrusted to the generosity and to the devoted service of the generations that

His Majesty, in replying, after paying a tribute to the Chancellor, proceeded:- "For the wonderful progress of higher education in the country we have largely to thank the great universities established in our principat cities. No nobler object for-munificence can be found than the provision for the necessary equipment for such education; an equipment which, in view of the diverse and elaborate requirements of the modern schools of instruction, must be costly: but without which these schemes, however carefully designed, will prove fruitless. Such institutions as this are of paramount importance in enabling students to NO. 2072 , VOI. 8I] obtain in their native city instruction in science and technology, in art and mathematics, which in former days they were: compelled to seck in places far distant from their homes, at an exponse which in some instances they could ill afford. The universties also foster a wholesome? rivialry, and encourage: the growth of the highest form of public spirit. A man educated at this Liniversity will be a better citizen of Birmingham, and a better subject of the Fimpire."

At the close of the opening ceremony, their Majesties inspected a part of the departments of civil and alcetrical engrinecring.

\section{THE SCIENCE COLIECTIONS AT SOUTH KENSINGTON.}

THE question of the worthy housing of the science collections at South Kensington has been brought before the Government on several occasions during the last thirty vears or so. The object of a deputation which waited upon Mr. Runciman at the Board of Education on Tuesday was again to endeavour to obtain an assurance that the Government will provide the money for the buildng of a museum in which the science collections can be exhibited as satisfactorily as are those of art. The deputation included distinguished representatives of the leading scientific societies and institutions, and the memorial which was presented was signed by the president and officers of the Royal Society, all its living past-presidents, and 128 of its Fellows distinguished in physical science; the Chancellors of the Universities of Cambridge, London, (Glasgrow, and st. Andrews; the Vice-Chancellors of the British universities; the presidents of scientific societies and institutions; professors of chemistry, physics, mathematics, astronomy, and engineering in all the British universities, university colleges, and principal technical schools and polytechnics; the directors of the chief polytechnics in London and in the provinces; and a very large and distinguished body of persons eminent in and interested in British science and desirous of its promotion.

There can be no doubt, therefore, as to the opinion of representatives of physical science upon the urgent need of satisfactory provision for the housing of the science collections. As Sir William Anson said in introducing the deputation. "the muscum, which represents the application of science to material, should be placed in the same position as art and natural history by the Government of the country."

The collections should be in a suitable building, with room for rearrangement and expansion. A site is available at South Kensington if the Government will come forward with the offer of funds for the actual building; but in spite of the memorial and the deputation, Mr. Runciman did not give an assurance that the money will be forthcoming. He was sympathetic and promised to place the matter before the Prime Minister and the Chancellor of the Exchequer, and with this result we must be satisfied for a while. $\Lambda$ useful purpose has certainly been served by bringing the subject into public view. We can now only hope that the Government will rise to the opportunity and offer to the phrsiral sciences, which are closely connected with the industries of this country, the same advantages for its collections as are already possessed by natural history and by art.

From a full report of the deputation in Wednesday's Times we make the subjoined extracts.

The memorial presented by Sir llenry Roscoe was as follows :-

"We, the undersigned, being deeply interested in the practice and progress of British science, desire to bring before you the importance of the proper housing of the Science Collections at South Kensington. The permanent buildings now erected provide accommodation for art collections only; to complete the scheme a suitable building for the science collections is a necessity. The formation of a science museum representative of all branches of physical science, both pure and applied, has long engaged the attention both of the Government and of British scientific men. So long ago as 1874 the Duke of Devonshire's Commission on Science strongly recommended the establishment of such 
a museum, and in their fourth report the Commissioners state :- While it is a matter of congratulation that the British Museum contains one of the finest and largest collections in existence illustrative of biological science, it is to be regretted that there is at present no national collection of the instruments used in the investigation of mechanical, chemical, or physical laws, although such collections are of great importance to persons interested in the experimental sciences. We consider that the recent progress in these sciences and the daily increasing demand for knowledge concerning them make it desirable that the national collections should be extended in this direction, so as to meet a great scientific requirement which cannot be provided for in any other way.' Since these words were written a National Science Museum has been established, and the collections in it have been steadily enriched by many important acquisitions. These collections are at present housed in the old buildings at South Kensington known as the Southern Galleries and the Western Galleries. They now include models and copies of historical and modern philosophical apparatus of the greatest value to all interested in the progress of British science, and a large number of machines, instruments, and models of great interest as illustrating the origin and development of our most pregnant British inventions, together with such special collections as the unique series of models illustrating the history of shipbuilding.

"In 1876 the Royal Commissioners of the Exhibition of I85I offered to the Government of the day a sum of Ico, oool., together with a site on the Commissioners' ground, for the proper housing of this collection, under the condition that the Government should undertake its maintenance. In 1878 the Commissioners repeated their offer, and in 1879 this was declined by the Government. In I888 the land to the south of Imperial Institute Road, reaching to that conveved to the Government in 1864 for the erection of the Natural History Museum, and containing $4 \frac{1}{2}$ acres, was sold to the Government for $70,000 l$. This land has now been in part. permanently allocated to the main section of the new buildings of the Imperial College of Science and Technology and to the building in course of ereclion for the Meteorological Office and a post office. The remainder of the site is at present occupied partly by temporary buildings and partly by the old buildings-the "Southern Galleries" - which now afford accommodation for the machinery and naval architecture collections of the Science Museum. This portion of the site, adjoining as it does on the north the Imperial College and on the south the Natural History Museum, is well regarded as an ideal position for the long projected Science Museum, which would complete the magnificent group of museum buildings already erected at South Kensington.

" The cost of acquisitions for the current growth of such a science museum, it may be noted, is far less than that of a corresponding art museum. The value of art products in creases rapidly with age, whereas the scientific implements machinery, and apparatus, interesting from an historical point of view, have rarely any great commercial value. The art collections of the Victoria and Albert Museum are now in possession of splendid buildings. If the buildings provided for the science collections were equally worthy of the interests which they should serve, the objects now in the museum could be exhibited to much greater advantage. Moreover, those lacunae which mark sections of recent activity in discovery and invention would be more readily filled than they can be while the obviously temporary character of the accommodation suggests to those who hold objects of interest in the history and advance of science that the authorities have but little appreciation for such things.

"Other countries, notably France and Germany, have recognised the importance of preparing suitable buildings for their National Science Museums. In Paris the Museum of the Ecole des Arts et Métiers has a world-wide renown; and a National German Science Museum is now being built in Munich at the cost of 300,000 . England, the mother of so many great inventions that have proved to be pioneers in industrial arts, stands alone in having made no adequate provision for exhibiting and arranging in proper order her unique collections. The undersigned venture to urge upon you that the time has now arrived for action. Land sufficient for the purpose is in the Government's hands, and the Royal Commissioners of ' 5 I if approached NO. 2072 , VOL. $8 \mathrm{I}]$ by the Government with a definite building scheme would doubtless give it due consideration. 'The need is great, and the mass of British science workers will hail your favourable decision with gratitude.'

in his remaris, sir nenry Roscoe said that what is needed is a building adequate to the proper exhibition of the present collection, ana orye worthy of British science. The grant for science purposes is $1800 l$. ; that for art I $1,260 l$. The fact that with so small a grant the national science collections have reached so important and in many respects so unique a position has been partly due to the fact that the cost of acquisitions for the current growth of such a science museum is far less than that of the corresponding growth of an art museum. Land sufficient for the required purpose is in the hands of the Grovernment, and the Royal Commissioners of $185 \mathrm{I}$, so long ago as 1878 , offered to contribute Ioo,oool. towards a building for the Science Museum. Sir Archibald Geikie said that the council of the Royal Society desired him to express its keen sense of the importance of the collections and the need for better housing for re-arrangement and expansion. Sir David Gill said that, confining his remarks principally to the astronomical collection, he was much impressed with its extreme value, as it inclided apparatus of all periods, from the earliest days down to the present time. Mr. Alexander Siemens, expressing the view of the Institution of Civil Engineers, said that in the interest of students of engineering it is of the utmost importance that the collections should be housed with plenty of space, and should be as complete as possible. Sir Hugh Bell, as president of the Iron and Steel Institute, said his national pride was hurt when he went through the tuilding at South Kensington and saw the collections housed in a place erected about fifty years ago as refreshment-rooms or something of that sort. Paris, Munich, and Berlin are very much in advance of London in that matter. Dr. R. T. Glazebrook, director of the National Physical Laboratory, said that the physical collection at South Kensington is very inadequately housed and quite fails to represent the growth of that science in England. Mr. W. M. Mordey, president of the Institution of Electrical Engineers, said there is at present no adequate representation of their work in this country. Sir William Ramsay said it is practically impossible to gain any notion of the progress of chemistry from a visit to the collection. Sir George Darwin said that in going over the museum he was struck by two or three things-first, the great interest of the collection; secondly, the overcrowding of it ; and, thirdly, the extreme deficiency of the buildings in which it is housed.

Mr. Runciman, in the course of his reply, said :-The memorial which has been presented to the Board of Education and to me on the subject of this museum is one of the most weighty memorials that $I$ think has ever been received by any Minister. We not only provide, or intend to provide, an exhibition for the exposition and demonstration of the principles of science, but we provide illustrations of the applications of science and arts to industry, including models and actual examples of outstanding inventions which are of historical importance, and, as Sir Henry Roscoe has said, are absolutely irreplaceable. We have the greatest desire to maintain historical industrial processes, and we have special collections, such as those in which I myself am enormously interested-namely, naval architecture, models of machines, and astronomical instruments. The whole of these are of priceless value. But I quite recognise that they are in many respects incomplete; and I am also impressed with the fact, as indeed everybody is who knows the building in which that collection is housed, that the housing has a great deal to do with the collection in the buildings in their present state. I recognise that the collection, even at the present day, is dreadfully overcrowded. The best illustration of that lies in the fact that in the cases now erected in the museum we have found it necessary to provide for what may be called a basement exhibition. When one passes through the exhibition one sees a considerable number of persons kneeling down on the floor in order to see. what is in the basement of these cases. Anyone who is responsible for the museum can hardly avoid being ashamed of that condition of things. It is true that some parts of the galleries were put up as temporary buildings. They were part of the exhibition, I think, of 1862 , and it is remarkable that they have lasted 
so long. The whole difliculty is the very prosaic difficulty, I fear, of money and land. The South Kensington area, which now contains some of the most remarkable collections and some of the most valuable buildings in the world, has been very rapidly occupied. We cannot go south because of the Natural History Museum, and we are blocked on the north by the Imperial Institute, the Royal College of Science, and some of the other buildings, and $I$ cannot at the moment see in what direction it will be possible for us to expand. The magnificent work which has been done in the direction of art on the other side of the road certainly sets the pace, and I recognise with you that it is pressingly necessary that we should have a new building for our great science collection at the earliest possible date. The question of funds is affected to some extent by the hint thrown out by Sir Henry Roscoe of assistance from the 185 I Commissioners. I cannot imagine any better work to which the Commissioners could devote their funds than in giving assistance in the construction of new buildings. For the moment I will say no more than that I will transmit to my colleagues and lay before the Cabinet; the Prime Minister, and the Chancellor of the Exchequer the very valuable statement which you made, and I will use my own personal influence, for whatever it may be worth, to impress on them the neccssities of the case.

\section{ESKDALEMUIR OBSERVATORY.'}

W.E have received the annual report of the observatory department of the National Physical Laboratory for the year 1908, which is noteworthy as being the first report issued since the establishment of the new magnetic and meteorological observatory at Eskdalemuir. Readers of NATURE will be aware that the advent of electric tramways to the neighbourhood of the observatory at Kew has greatly interfered with magnetic work there. The new establish$m \in n t$ in Dumfriesshire is far removed from all industrial undertakings, and will thus be free from disturbing effects due to artificial causes.

So far as Eskdalemuir is concerned, the past year has been one of installation and experiment, and the report contains no results of observations. The superintendent, $\mathrm{Mr}$. G. W. Walker, went into residence on May $x \mathbf{1}, 1908$, and was followed shortly after by his staff, comprising observer, computer, mechanic, and mechanic's assistant. The first instruments to be set up were the Elliot unifilar magnetometer and the Dover dip circle, which were given to the laboratory by Sir Arthur Rücl:er. They are the instruments which were used by the donor and Prof. Thorpe in their magnetic survey of the Firitish Isles in 189o. The first absolute measurements of horizontal force declination, and inclination were made on May 29, and were continued for eight weeks, when some changes became necessary. Observations, made three times a week, were resumed in October, and have since formed part of the routine work of the observatory. The final determination of the azimuth of the fixed mark awaits the completion of the arrangements for the time signal.

The recording apparatus consists of a set of Eschenhagen magnetographs and a set of Kew pattern magnetographs made for the observatory by Mr. P. Adie. The former belong to the Admiralty, and are those used at the Discovery's winter quarters in 1902-4. Owing to damp, the magnetic house could not be used immediately, and the instruments had to be accommodated elsewhere. The Eschenhagen recorders were set up temporarily in the seismograph room. The Adie instruments were accommodated in the general laboratory, but the warping of the wooden supports has made satisfactory compensation for temperature changes impossible, and the point will have to be taken up again when the instruments are removed to their permanent positions.

For seismological work a twin-boom Milne seismograph is in use. Regular records have been obtained since September 24. Provision has also been made for carrying on the work of a meteorological observatory or station of the first order. The photographic barograph and wet-

1 The National Physical Laboratory. Report of the Ohservatory Denartment, Richmond, Surrey, and of the Observatory, Eskdalemuir. Langholm, Dumfriesshire, for the Year 1908, with Appendices. Pp. 53. (Teddington, x>og.)

NO. 2072 , VOL. 8I] and dry-bulb thermograph have been lent by the Meteorological Office. They are the identical instruments which were formerly in use at Fort William Observatory, the base station of Ben Nevis. A Dines pressure-tube anemometer, a Beckley autographic rain-gauge, a CampbellStokes sunshine recorder, and barograph and thermograph of Richard pattern complete the outfit of ordinary meteorological instruments. Provision has, of course, been made for the usual control readings and for eye observations of weather phenomena. An Ångström compensation pyrheliometer has also been set up, and preparation has been made for recording the atmospheric electrical potential.

At Kew the usual observing and testing work has been continued. Summaries of the magnetic and meteorological work are given in the appendix. The results of measurements of solar radiation with an Angström pyrheliometer, and of the temperature of the soil at depths of $I$ foot and 4 feet, are given for the first time. The examination of the apparatus to be used at Eskdalemuir has formed an important part of the year's work, and we note also that Mr. W. Dubinsky, of the Pavlovsk Observatory, spent some time at Kew for the purpose of making comparisons between the Kew standard magnetometers and barometer and the standards in use in Russia. These comparisons were carried out in accordance with a general scheme for the international comparison of standards approved by the last International Meteorological Conference. The report concludes with the usual summaries of the magnetic results obtained at the observatories at Falmouth and Valencia.

THE IMPERIAL CANCER RESEARCH FUND.

THE annual meeting of the general committee of the Imperial Cancer Research Fund was held on July 9 at Mariborough House, when the Prince of Wales, the president of the organisation, took the chair.

The following are extracts from the report, which was adopted at the meeting :-

During the past year further correspondence took place with the authorities of the International Society for Cancer Research in Berlin, in which it has been suggested that the executive committee should re-consider the attitude hitherto adopted and join the International Society; and offering that the first International Congress should be held in London. The executive committee is of opinion that the decision arrived at is in the best interests of the scientific investigation of cancer, and accordingly it adhered to its position. At a subsequent date a petition was presented by the International Society for Cancer Research. in Germany to the King, as patron of the Imperial Cancer Research Fund, asking that the decision might be reviewed, but His Majesty, after considering the facts submitted to him through the Foreign Office, expressed the view that the Imperial Cancer Research Fund has cooperated freely in the past, both with German and other foreign workers, and will continue to do so in the future.

It may be well to recall in this connection the extent to which the Imperial Cancer Research Fund has encouraged the investigations of independent workers both at home and abroad. As is well known, the material for experimental research is difficult and costly to obtain, and is beyond the reach of many who, but for the help given from this fund, would be debarred from participation in this branch of the research. Recognising that such help must be of the first importance, it has been the aim of the general superintendent, Dr. E. F. Bashford, with the entire concurrence of the executive committee, to distribute to all applicants who possess the necessary credentials the material accumulated with much labour and expense.

A satisfactory feature of the past year has been the recognition of the work of the fund by foreign investigators, as is shown by the number of applicants for permission to work under the general superintendent. It has been found impossible to concede all the requests, but gentlemen from Italy, Bukarest, . New York, and Munich have been accorded full. liberty to pursue their researches in the laboratories supported from the fund, and every facility has been given them. Special arrangements have also been granted to other workers to pursue certain specific investigations, and to certain foreign medical men to study the methods during a short visit to this country. 